\title{
ROOF GARDENS AS LANDSCAPING IN MODERN TIMES
}

\author{
Vaska Sandeva, Katerina Despot, Dejan Clakov \\ Goce Delcev University of Stip, R. Macedonia \\ Krste Misirkov b.b. P.O. Box 201 Stip 2000, Macedonia, \\ e-mail: vaska.sandeva@ugd.edu.mk katerina.despot@ugd.edu.mk
}

\begin{abstract}
As we know we live in a process of industrialization and massive building of residential buildings, both individually and as a collective housing. Given all that happens even with the procedural other things to come up with all this, the country remains less green space that is required for a single environment, so the roof gardens are the best choice for all of this to get a beautiful country. For roof gardens should be given the explanation that, roof gardens, call it beautiful, flat roofs, and with gentle slope, with rich composition intensively maintained and often impose a constructive adaptation of the building and benefits by the architectural beauty, insulation, absorption. Commonly found in urban areas and almost always are placed foliage with not very high growth.
\end{abstract}

Keywords: landscaping, gardens, benefits.

\section{A HISTORY REVIEW OF THE ROOF GARDENS}

The origins of the roof gardens are getting us a millennium ago in the Babylonian Empire, where was assumed that the existence of the earliest hanging gardens on Semiramida, the one of the Seven World Wanders.

From historical view, roof gardens are connected with the coulomb for Adonis - Phoenician god, the symbol of the blossom, It's assumed that the coulomb was like, whenever he died (every single year) he was buried on the roofs of the houses and that's why the roofs and the balconies have been decorated with vegetation.

On the balconies there were clay pots, where the fast growing flowers were placed. The Adonis Holiday was respected even in the Empire Rome and Empire Greece.

Ever since then the people realized that every single free vent, even though it's not on the land, have to be used for vegetation, just like the Romans have used their roofs and balconies for growing plants.

The roofs of wealthier owners of the villas were converted in gardens with lakes. On the Kings boat, that kind of gardens with lakes was there.

The roofs of the villas in Germany and Italy, in the renaissance, represented big collections of foreign plants, that are collections of plants brought for the other sides of the Earth.

If we give a review of the roof gardens we will become aware that in the past they were built for beautification of the area and the architecture of the object itself, but today they are built because of a need of not having enough vent for green areas, therefore the roof gardens are made, like a target for air filtering, beautification of the area and the others benefits they have.

\section{THE INDUSTRIALIZATION PROCESS, REASON TO BUILD ROOF GARDENS}

We live in the time of industrialization and modern architecture. In the present the bigger meaning is given and the bigger swing is taken by modern buildings and the industrialization, but getting to these two processes, a sacrifice is needed. 


\section{ARTTIE $Y$}

Ipplied Researthes in Technics, Technologies and Eduration

Journal of the Faculty of Technics and Technologies, Trakia University https://sites.google.com/a/trakia-uni.bg/artte/

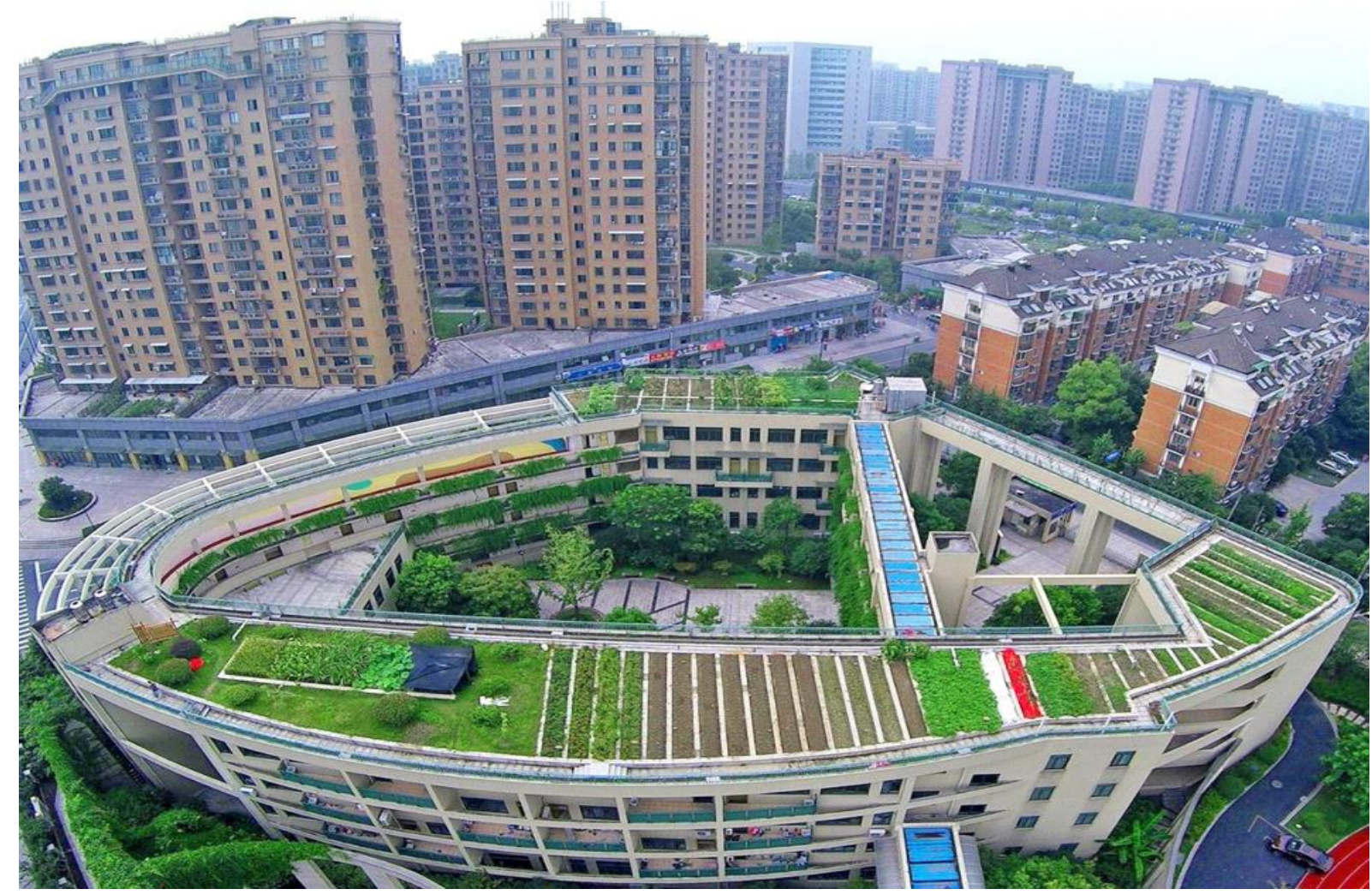

Figure 1. Roof garden in the central city area

In these cases the greenery is sacrificed that is on the Earth land that means the "city lungs" are sacrificed. The expense of the pollution air and unhealthy environment, these two processes are building and implemented, to which, we all agree that they are modern and necessary in the modern society, but not taking the swing completely, that means to be built by the cost of the green area that has existed for a long time.

To overcome all of this, even in small measures, and a green area is placed again, even though on the place of the old green area some architectural object is already built, the roof gardens are built. They are mostly used and we can see them in the downtowns of the big cities, because there is no space for them on the Earth land for the green area to be build and maintained, therefore the roof gardens are made.

\section{THE MEANING OF THE ROOF GARDENS FOR THE ENVIRONMENT}

The roof gardens are mostly found in the downtowns of the cities, on the roof constructions of the residential objects for collective housing, business objects or individual residential or business objects.

The plants that are used in the roof garden formation, have ability to reduce the heat loss of the building, that means to maintain the inner ceiling part of the building, while without them there will be a huge heat loss. 


\section{IRTITE}

Ipplied Resseirlches in Teechnics, Technologies and Eductition

Journal of the Faculty of Technics and Technologies, Trakia University https://sites.google.com/a/trakia-uni.bg/artte/

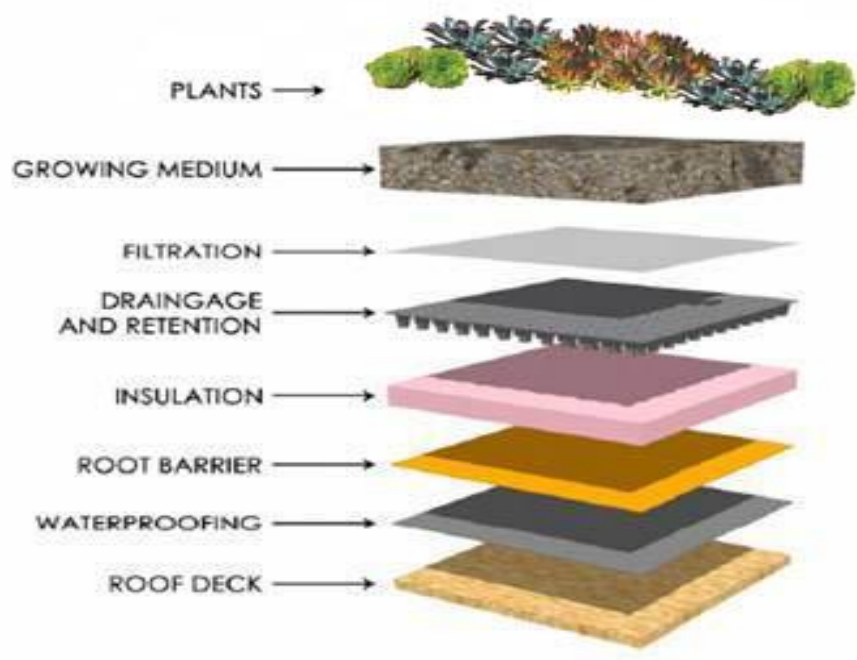

Figure 2. Green roof layers

Also, they are not allowing the sunlight that is coming from the exterior ceiling, to be directly missed inside, but a part will be held with the help of the green roof vegetation and they will be transformed in heating energy.

One study of the International Canada Council of Research, demonstrated differences, between roofs with and roofs without gardens, in regarding of the temperature. The study shows that the temperature effects on different layers, on every roof in different periods of the day. In that view the roof gardens are obviously very useful, and in the terms of the absorption, power saving, as well as the heat in the certain periods of the day and certain periods of the year.
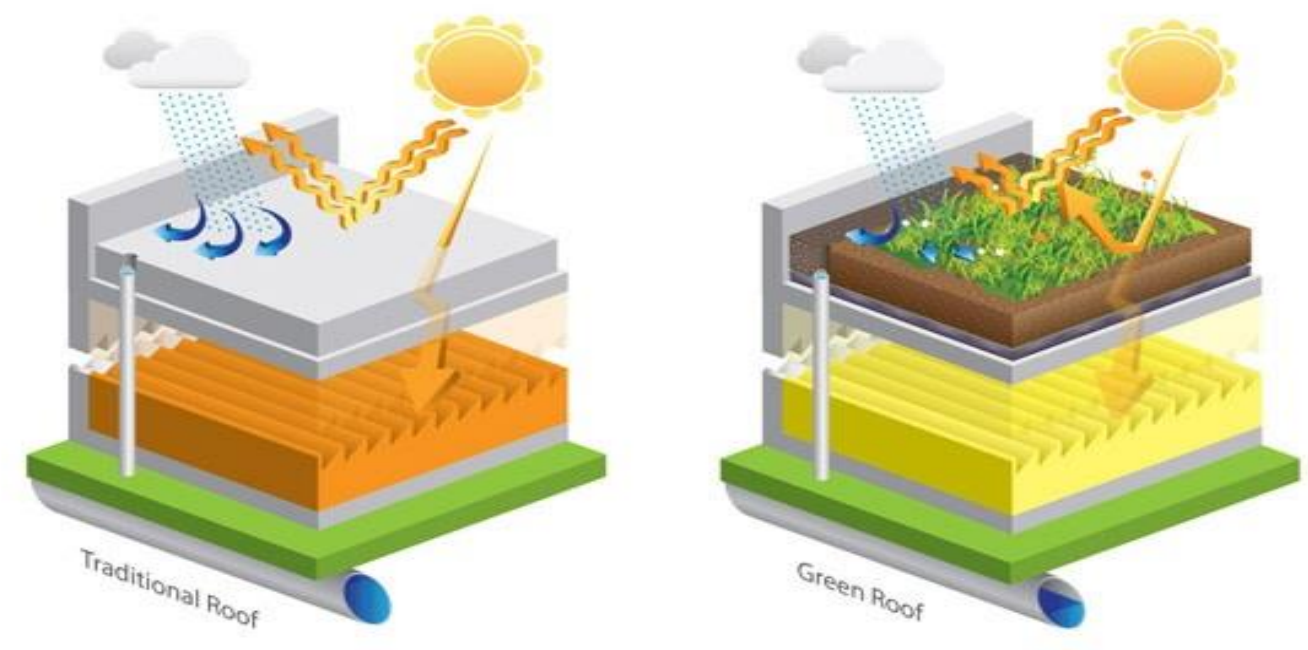

Figure 3. Green roof comparison

IRTIIE Vol. 4, No. 2, 2016 ISSN 1314-8788 (print), ISSN 1314-8796 (online), doi: 10.15547/artte.2016.02.010 


\section{ARTTIE Y}

Ipplied Reseirlches in Teechnics, Technologies and Eductition

Journal of the Faculty of Technics and Technologies, Trakia University https://sites.google.com/a/trakia-uni.bg/artte/

Except the isolation, if the roof gardens own plant species with higher growth, there will be possibility of air cleaning.

In the big cities, there is a big problem with the atmospheric sewers, which means that if there are no atmospheric sewers, all the storm water will flow in the fecal sewage, which leads to overload the sewerage grid, and that leads to pipes cracking, frequent outbursts etc. If we want to prevent, even a part, we can find the roof gardens useful. They can hold big part of the storm water for themselves, and one part through their drainage, is thrown to the sewerage grid. If every single building in the downtown of the city has roof garden and there is no atmospheric sewerage, we will automatically gain a reduction of water that will be permeated in the sewerage grid, there will be burden reduction, as well as the risk of pipes cracking and overflowing.

The existing roof gardens, increase the value of the object where they are placed, which means that the investor will recover twice more money from the value of the investment for construction, as well as the object, and also the roof garden, because they provide a good ambience, isolation, clean air, and a place for rest and relaxation for the buyers and the visitors

Certainly, from the financial point this is much valuable option, a roof garden to be built on some an existing and paid building, than buying a land and building a new green oasis. In the developed countries, this is even more valuable, because in some of them, the legislation stimulate this kind of ventures.

\section{ROOF GARDENS AROUND THE WORLD}

\subsection{Villa Bio by Enric Ruiz-Geli}

The green roof design of Villa Bio stands out amongst a community of cookie-cutter, Mediterranean-style homes in Llers, Spain. While it was first met with controversy, the completed Villa Bio reflects the nature of the local landscape much more intimately than its neighbors. That nature does not end at the corner of its plot, but continues on to the home's hydroponic garden that snakes along its green roof. Architect Enric Ruiz-Geli has masterfully designed a home with a seamless connection with the Mediterranean environment, an organically-inspired structure with a lush, productive green roof.

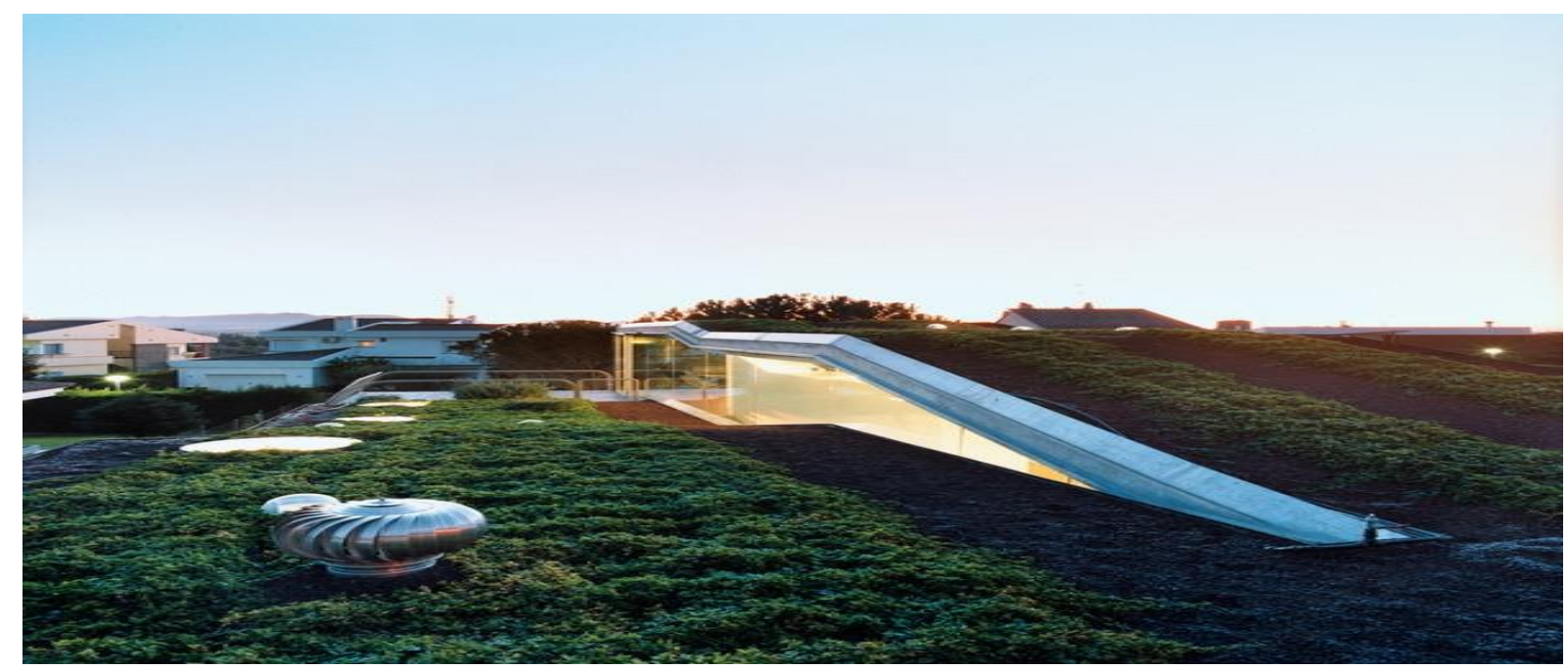

Figure 4. Villa Bio by Enric Ruiz-Geli

IRITIE Vol. 4, No. 2, 2016 ISSN 1314-8788 (print), ISSN 1314-8796 (online), doi: 10.15547/artte.2016.02.010 


\section{ARTTIE $Y$}

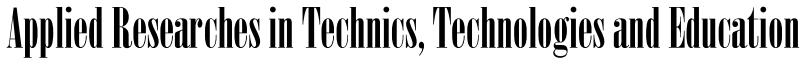

Journal of the Faculty of Technics and Technologies, Trakia University https://sites.google.com/a/trakia-uni.bg/artte/

\subsection{Mill Valley Residence by McGlashan Architecture}

This terraced, multi-family home in Mill Valley, California is as hilly and green as the environment around it. The Mill Valley Residence by McGlashan Architecture includes three sections, each with its own green roof, built into the hill of the lot. The green roof design of the Mill Valley Residence may not produce vegetation of the garden variety, but plants that hail from the home's local flora. The result is a stunning home with a green roof that reduces heating and cooling costs and stimulates the habitat of local Mill Valley wildlife.

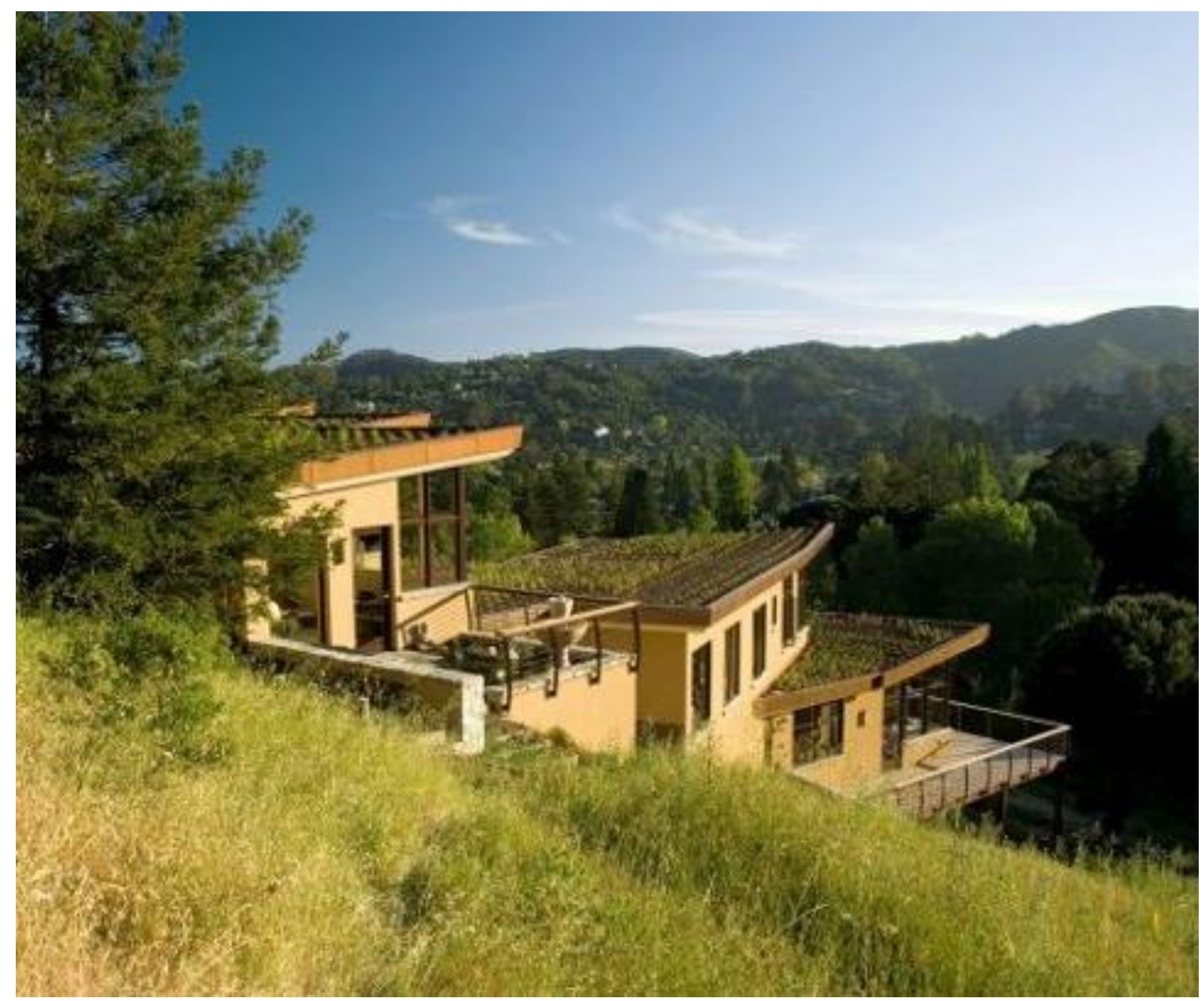

Figure 5. Mill Valley Residence by McGlashan Architecture

\subsection{Mountain Dwellings by BIG Architects}

The Mountain Dwellings by BIG Architects features a green roof design on a grand scale. The Mountain Dwellings comprise 80 single-family units, each with its own private "back yard", a green roof over the unit below. Due to the sloping nature of the structure, each green roof deck is out of view of the unit below and above it, with privacy fences separating the units side-by-side. The Mountain Dwellings of Copenhagen provide city living and the back yard feel of suburban life, thanks to a brilliant green design by BIG Architects.

IRITIE Vol. 4, No. 2, 2016 ISSN 1314-8788 (print), ISSN 1314-8796 (online), doi: 10.15547/artte.2016.02.010 


\section{ARTTIE $Y$}

Ipplied Reseirlches in Teechnics, Technologies and Bducation

Journal of the Faculty of Technics and Technologies, Trakia University https://sites.google.com/a/trakia-uni.bg/artte/

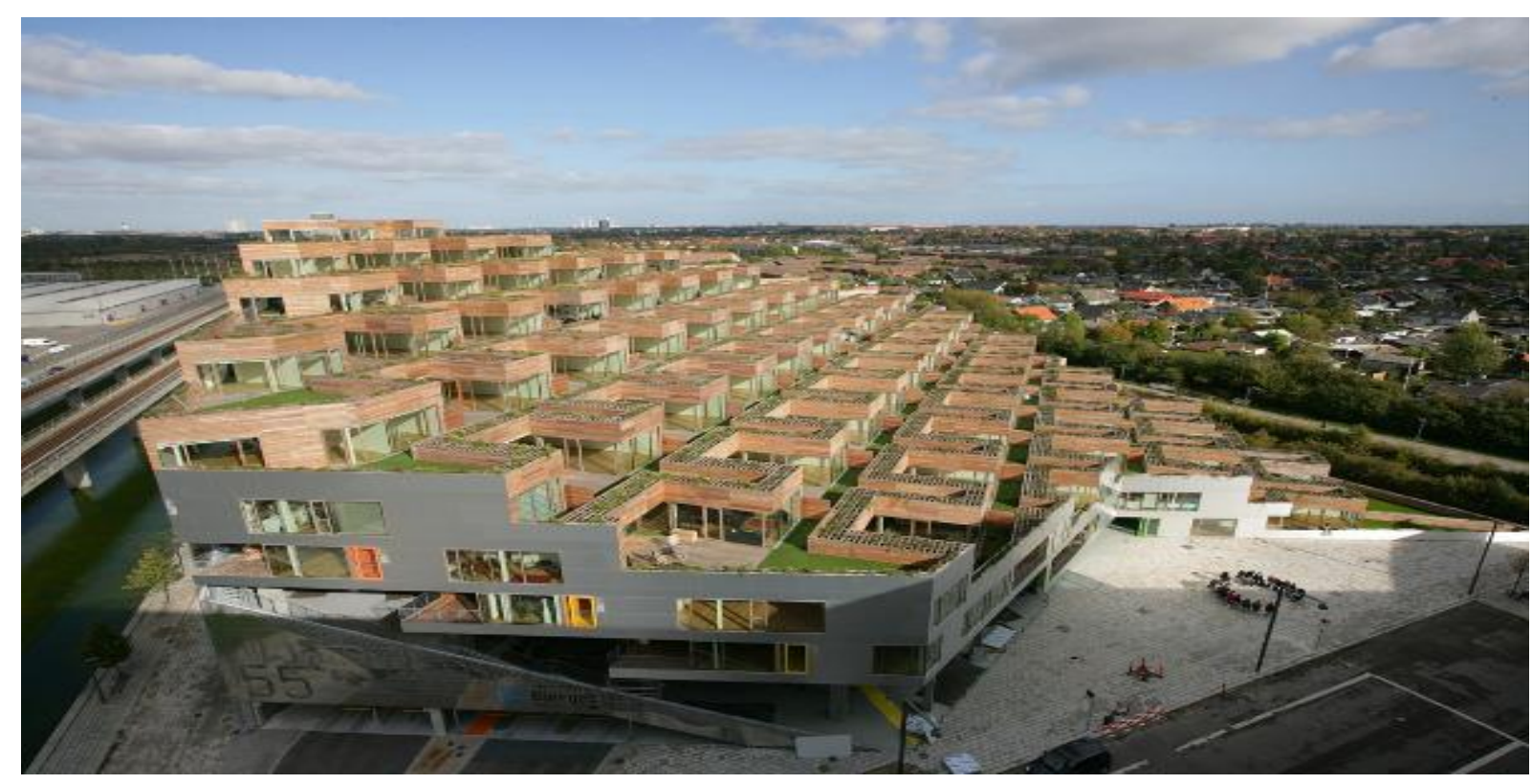

Figure 6. Mountain Dwellings by BIG Architects

\subsection{Nanyang School of Art}

The Nanyang Technological University of Singapore recently erected a green roof building to house their School of Art, Design and Media. The five story structure features two curved sections with stretches of green roof fully accessible to students. In the Nanyang School of Art, the line between landscape and building are blurred. Beyond the aesthetic value of this green roof design, this living skin saves heating and cooling costs and collects rainwater for landscape irrigation.

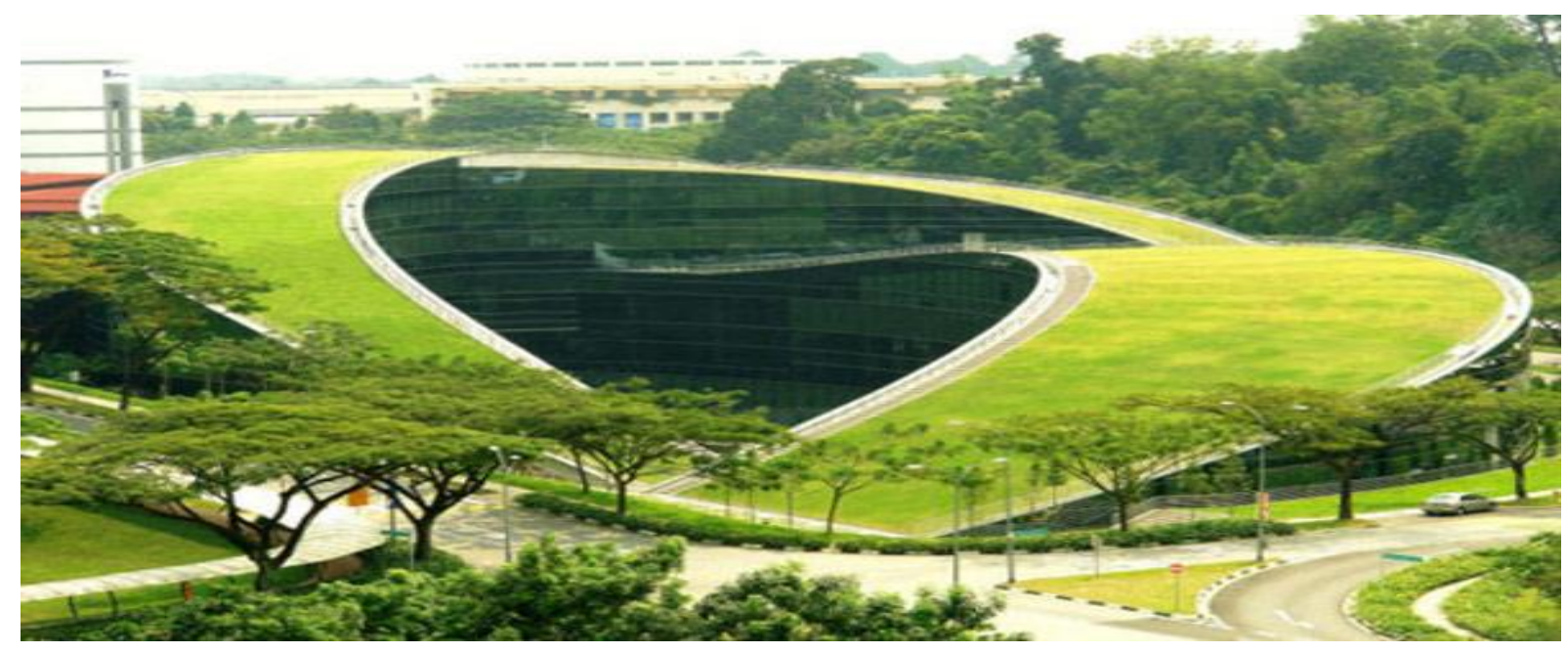

Figure 7. Nanyang School of Art 


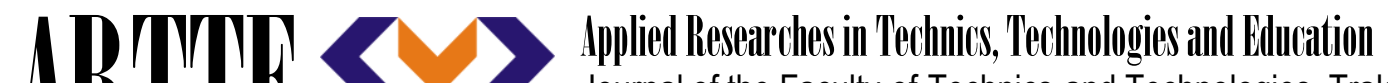 IITH Journal of the Faculty of Technics and Technologies, Trakia University https://sites.google.com/a/trakia-uni.bg/artte/}

\section{CONCLUSION}

With the more recent projects, and the more recent investigations, as well as the mentioned examples in this labor, we can make a conclusion that every object of any kind of culture and any kind of purpose it has, it can possess green area. If there is not enough space for green area around the object, that can be achieved with projecting a roof garden.

The roof gardens are becoming common place in the big cities centers, so they are starting to be practiced all around the World, like a object beautification, a costs of heat and cooling reducers, as well as rainwater accumulation.

The roof gardens will become necessary in every new object in a short time.

We can make a conclusion that, the societies have to stimulate this kind of ventures, by implementation more project for roof gardens like a future modern and effective landscaping.

\section{LITERATURE}

[1] Feng Haibo (2008). Lifecycle Based Energy Assessment of Green Roofs and Walls.

[2] Green roof plants: A resource and planting guide by Edmund C. Snodgrass and Lucie L. Snodgrass.

[3] Green Roofs: Ecological design and construction by Earth Pledge.

[4] Green roofs: A guide to their design and installation by Angela Youngman.

[5] Planting green roofs and living walls by Nigel Dunnett and Noel Kingsbury.

[6] http://www.savour-garden.com/roof_gardens.htm.

[7] http://www.thecoolist.com/green-roof-design/.

[8] https://en.wikipedia.org/wiki/Green_roof. 